\title{
KIEDY I GDZIE ZOSTAŁA WYSTAWIONA CHILANDARSKA POVELJA STEFANA NEMANJICIA?
}

\author{
BŁAŻEJ SZEFLIŃSKI
}

\begin{abstract}
When and Where Was the Charter for Hilandar of Stephen Nemanjic Given?
The so-called Second Charter for Hilandar given by Stephen Nemanjić is one of the oldest Serbian documents that preserved to our times. It dates itself on $29^{\text {th }}$ September, but without any year or indiction. Since the publishing of Aleksandar Solovjev's paper in 1925 it had been commonly accepted that the charter was given before 1202 because Stephen Nemanjić could name himself the son-in-law of emperor Alexios III Angelos only before the divorce with Eudokia Angelina. However, in 2010 Đorđe Bubalo has noticed that two later inscriptions - discovered after Solovjev's research - also emphasize family connections between Nemanjić dynasty and Alexios, so the argument used by Solovjev cannot be held. Therefore, Bubalo has reanalysed the charter and suggested a new dating - to 1207-1208. However, one of his arguments - the Second Charter for Hilandar was used by Sava Nemanjić when writing the Life of Blessed Symeon - has lost its strength as such a relation between these texts is questioned in the newest research. Therefore, the objective of the hereby paper is to provide a new analysis of the Second Charter for Hilandar focused on when and (for the first time) where the document was given. The conclusion is that it happened after the hierophany of St Symeon - most probably on $29^{\text {th }}$ September 1210 in the Hilandar monastery.
\end{abstract}

STRESZCZENIE. Tak zwana Druga chilandarska povelja Stefana Nemanjicia jest jednym z najstarszych serbskich dokumentów zachowanych do naszych czasów. Jest ona opatrzona datą 29 IX, ale bez żadnego roku ani indykcji. Od publikacji artykułu Aleksandara Solovjeva w 1925 r. powszechnie przyjmowano, że przywilej został wystawiony przed 1202 r., ponieważ Stefan Nemanjić mógł nazwać siebie zięciem cesarza Aleksego III Angelosa jedynie przed rozwodem z Eudoksją Angeliną. Jednak w 2010 r. Đorđe Bubalo zauważył, że dwie późniejsze inskrypcje - odkryte po badaniach Solovjeva - również podkreślają powiązania rodzinne pomiędzy dynastią Nemanjiciów a Aleksym, więc argument Solovjeva nie może zostać utrzymany. Z tego powodu Bubalo ponownie przeanalizował przywilej i zaproponował nowe datowanie - na lata 1207-1208. Jednak jeden z jego argumentów - Druga chilandarska povelja wykorzystana przez Sawę przy pisaniu Żywota błogosławionego Symeona - stracił swoją siłę, gdyż taki związek pomiędzy tekstami został zakwestionowany w najnowszych badaniach. Z tego powodu celem niniejszego artykułu jest dostarczenie nowej analizy Drugiej chilandarskiej povelji skoncentrowanej na tym, kiedy i (po raz pierwszy) gdzie dokument został wystawiony. W konkluzji stwierdzono, że miało to miejsce po hierofanii św. Symeona - najprawdopodobniej 29 IX 1210 r. w Chilandarze.

Author: Błażej Szefliński

Keywords: Stephen Nemanjić, charter, Hilandar monastery, Vukan Nemanjić, Sava Nemanjić, hierophany, St Symeon, Serbia

Slowa kluczowe: Stefan Nemanjić, przywilej, monaster Chilandar, Vukan Nemanjić, Sawa Nemanjić, hierofania, św. Symeon, Serbia

Balcanica Posnaniensia. Acta et studia, XXVI, Poznań 2019, Wydawnictwo Instytutu Historii UAM, pp. 93-104, ISBN 978-83-66355-32-3, ISSN 0239-4278. Polish text with summaries in English and Polish.

doi.org/10.14746/bp.2019.26.6 
W 1198 roku została założona jedna z najważniejszych, jeśli nie najważniejsza, instytucja w dziejach serbskiego narodu - monaster Chilandar ${ }^{1}$. Wiązało się to z wystawieniem koniecznych dokumentów, najpierw bulli cesarza Aleksego III Angelosa ${ }^{2}$, a następnie dwóch przywilejów fundacyjnych. Jeden z nich, znany jako Pierwsza chilandarska povelja, został wystawiony przez byłego władcę Serbii Stefana Nemanję zamieszkującego górę Atos jako mnich Symeon ${ }^{3}$, a drugi - przez jego najmłodszego syna Sawę. Ten ostatni dokument się niestety nie zachowal' ${ }^{4}$ W jakiś czas później średni syn, a zarazem następca Nemanji na tronie wielkożupańskim, Stefan Nemanjić nadał monasterowi kolejny przywilej, nazywany przez dzisiejszych badaczy Druga chilandarska povelja ${ }^{5}$. Dokument ten stał się przedmiotem wielu różnych badań z zakresu językoznawstwa ${ }^{6}$, literaturoznawstwa ${ }^{7} \mathrm{i}$ historii ${ }^{8}$. Niniejszy artykuł przynależy do tej ostatniej grupy.

Ponieważ przywilej opatrzony jest wyłącznie datą dzienną (29 IX), bez daty rocznej i bez indykcji ${ }^{9}$, historycy usiłowali ustalić czas jego wystawienia na podsta-

${ }^{1}$ М. Живојиновић, Историја Хиландара I: Од оснивања манастира 1198. до 1335. године, Београд 1998, s. 53-67; B. Szefliński, Trzy oblicza Sawy Nemanjicia: postać historyczna - autokreacja - postać literacka, Łódź 2016, s. 56-60.

2 Actes de Chilandar, t. I, Des origines à 1319, éd. M. Živojinović, V. Kravari, Ch. Giros, Paris 1998, s. 104-110 (dok. nr 4); Ф. Баришић, Преводи грчких повеља о оснивању српског Хиландара, „Књижевност”, 1986, t. 83/8-9, s. 1220-1223 (serbski przekład).

${ }^{3}$ Ђ. Трифуновић, В. Бјелогрлић, И. Брајовић, Хиландарска оснивачка повеља светога Симеона и светога Саве, w: Осам векова Студенице: зборник радова, Београд 1986, s. 49-60 (tekst cerkiewnosłowiański i serbski przekład); Зборник средњовековних ћириличких повеља и писама Србије, Босне и Дубровника, књ. 1: 1186-1321, прир. В. Мошин, С. Ћирковић, Д. Синдик, ред. Д. Синдик, Београд 2011 (dalej: Зборник повеља), s. 67-69 (dok. nr 9).

${ }^{4}$ B. Szefliński, Trzy oblicza, s. 60.

${ }^{5}$ Стефан Првовенчани, Сабрана дела, прир., прев. и комент. Љ. Јухас-Георгиевска, изд. Т. Јовановић, Београд 1999 (dalej: Стефан Првовенчани), s. 2-13 (tekst cerkiewnosłowiański i serbski przekład); Selected Charters of Serbian Rulers (XII-XV Century) Relating to the Territory of Kosovo and Metohia. Part 1, ed. and transl. by T. Živković, S. Bojanin, V. Petrović, Athens 2000, s. 27-36 (dok. nr 2) (tekst cerkiewnosłowiański i angielski przekład); 3борник повеља, s. 79-83 (dok. nr 12). Druga spośród wymienionych publikacji niestety nie była mi dostępna.

${ }^{6}$ В. Јерковић, Језик повеље великог жупана Стефана Немањића манастиру Хиландар, „Зборник Матице српске за филологију и лингвистику” (dalej: ЗМСФЛ), 1997, t. 40/2, s. 123-139; idem, Синтаксичке одлике хиландарске повеље Стефана Немањића, ЗМСФЛ, 1998, t. 41/2, s. 19-33.

${ }^{7}$ С. Радојчић, Хиландарска повеља Стефана Првовенчаног и мотив раја у српском минијатурном сликарству, „Хиландарски зборник” (dalej: Х3), 1966, t. 1, s. 41-50; Р. Маринковић, Почеии формирања српске биографске књижевности: повеље о оснивању манастира Хиландара, „Прилози за књижевност, језик, историју и фолклор” (dalej: ПКЈИФ), 1973, t. 39/1-2, s. 3-19 (=Р. Маринковић, Српске повеље о оснивану манастира Хиландара, w: idem, Светородна господа српска: истраживања српске књижевности средњег века, Београд 2007, s. 39-56); И. Шпадијер, Алегорија раја код Светог Саве и Стефана Првовенчаног, w: ПЕРІВОАОЕ: Зборник у част Мирјане Живојиновић, t. I, уред. Д. Џелебџић, Б. Миљковић, Београд 2015, s. 113-126.

8 А. Соловјев, Хиландарска повеља великог жупана Стефана (Првовенчаног) из године 12001202., ПКЈИФ, 1925, t. 5/1-2, s. 62-89; Ђ. Бубало, Када је велики жупан Стефан Немањић издао повељу манастиру Хиландару?, „Стари српски архив”, 2010, t. 9, s. 233-241.

${ }^{9}$ Стефан Првовенчани, s. 12-13. 
wie treści. Jako pierwszy rzetelnego zbadania tego problemu podjął się Aleksandar Solovjev ${ }^{10}$. Datował on dokument na lata 1200-1202, uważając za najważniejszą wskazówkę fakt, że Stefan nazwał siebie zięciem cesarza Aleksego. Z tego powodu uczony był przekonany, że przywilej musiał zostać wystawiony jeszcze w czasie małżeństwa Stefana i Eudoksji Angeliny. Natomiast terminus post quem badacz ten upatrywał w dacie śmierci Symeona (nazwanego w dokumencie świętym), która jak sądził, miała miejsce 13 II 1200 r. Dokonana przez Franja Barišicia korekta daty śmierci Symeona na 13 II 1199 r. ${ }^{11}$ cofnęła cezurę początkową o rok. Stan taki utrzymywał się w nauce aż do roku 2010, kiedy to Đorđe Bubalo wskazał, że w świetle inskrypcji nieznanych w momencie publikacji pracy Solovjeva ${ }^{12}$ jego główny argument wyznaczający terminus ante quem nie może zostać utrzymany ${ }^{13}$. Z tego powodu Bubalo przeprowadził ponowną analizę danych zawartych w dokumencie. Skłoniła ona serbskiego uczonego do datowania przywileju na okres pomiędzy przeniesieniem kości Symeona z Chilandaru do Serbii a powstaniem Żywota błogosławionego Symeona napisanego przez Sawę, czyli na lata $1207-1208^{14}$. Datowanie takie opiera się na przekonaniu, że tekst Żywota był zależny od tekstu przywileju, ugruntowanym wcześniej w opracowaniach ${ }^{15}$. Bubalo nie dostrzegł jednak, że o ile powiązanie genetyczne obu tekstów jest niezaprzeczalne, o tyle twierdzenie o zależności tekstualnej Żywota od

${ }^{10}$ А. Соловјев, ор.cit., s. 75-76. Wcześniejsze uwagi na ten temat były tak powierzchowne, że nie warto ich tu nawet przytaczać.

11 Ф. Баришић, Хронолошки проблеми око године Немањине смрти, Х3, 1971, t. 2, s. 31-58.

12 Mowa tu o dwóch inskrypcjach wskazujących na powinowactwo łączące Stefana Nemanję bądź Stefana Nemanjicia z cesarzem Aleksym, powstałych już po rozwodzie z Eudoksją i po detronizacji jej ojca. Pierwsza to inskrypcja fundacyjna w Studenicy. С. Мандић, М. Лађевић, Откривање и конзервирање фресака у Студеници, „Саопштења”, 1956, t. 1, s. 38-39 (odkrycie); С. Мандић, Древник: записи конзерватора, Београд 1975, s. 81-83 (rekonstrukcja ubytków); Б. Миљковић, Студеница, Богородичина ирква (1208/9), w: Г. Суботић, Б. Миљковић, И. Шпадијер, И. Тот, Натписи историјске садржине у зидном сликарству, t. I, XII-XIII век, уред. Љ. Максимовић, Београд 2015, s. 35-44 (najnowsze wydanie z obszernym komentarzem). Druga to podpis przy portrecie Stefana w Mileszewie. Ђ. Бошковић, Неколико натписа са зидова српских средњевековних цркава, „Споменик Српске краљевске академије”, 1938, t. 87, s. 5 (pierwsze wydanie); В.J. Ђурић, Српска династија и Византија на фрескама у манастиру Милешеви, „Зограф”, 1992, t. 22, s. 15, 18 (nowe odczytanie); Ђ. Трифуновић, Натписи уз портрете Немањића у манастиру Милешеви, „Књижевност и језик”, 1992, t. 39/2-4, s. 99 (nowe odczytanie). Powinowactwo to podkreślano ze względów ideologicznych. Б. Миљковић, op.cit., s. 38-42; С. Пириватрић, Грчки цุар Алексије у првим житијима Светог Симеона Немање, „Зборник радова Византолошког института” (dalej: ЗРВИ), 2016, t. 53, s. 164 i n.

13 Ђ. Бубало, op.cit., s. 235.

14 Ibidem, s. 240.

15 А. Соловјев, ор.cit., s. 77-80; Р. Маринковић, Историја настанка „Живота господина Симеона" од светога Саве, w: Сава Немањић-Свети Сава. Историја и предање, уред. В. Ђурић, Београд 1979, s. 201-213 (=Р. Маринковић, Историја настанка „Живота господина Симеона” од светога Саве, w: idem, Светородна господа српска: истраживања српске књижевности средњег века, Београд 2007, s. 99-114); Д. Богдановић, Историја старе српске књижевности, Београд 1980, s. 151; М. Кашанин, Српска књижевност у средњем веку, Београд 2002, s. 116; Р. Станкова, Сръбската книжнина през ХІІІ в. (контекст и текст), София 2007, s. 104-109. 
povelji było tylko interpretacją bazującą na wcześniejszym datowaniu przywileju. Za sprawą wskazanej przez uczonego możliwości późniejszego datowania w najnowszych pracach zaproponowano innego rodzaju powiązania genetyczne pomiędzy obydwoma tekstami ${ }^{16}$. Dlatego też pojawia się potrzeba ponownego przeanalizowania wszystkich przesłanek i ustalenia nowego datowania, zgodnego z aktualnym stanem wiedzy. Jeśli natomiast chodzi o kwestię miejsca wystawienia dokumentu, to - o ile mi wiadomo - nikt do tej pory nie przedstawił żadnych rozważań na ten temat ${ }^{17}$.

Tekst przywileju dostarcza kilka przesłanek dotyczących czasu i miejsca jego wystawienia:

1. Stefan tytułuje się wielkim żupanem ${ }^{18}$, co oznacza, że dokument musiał powstać przed jego koronacją królewską. Nie znamy dokładnej daty tego wydarzenia. Andrzej Dandolo w swoim dziele Chronica per extensum descripta zapisał, że w 12 roku rządów doży weneckiego Piotra Zianiego (czyli od 5 VIII 1216 do 5 VIII 1217 r.) Anna Dandolo, wnuczka nieżyjącego już doży Henryka Dandolo, poślubiła wielkiego żupana Serbii Stefana, a następnie przekonała go do porzucenia wiary schizmatyckiej (tj. prawosławnej) i przejścia na katolicyzm, po czym obydwoje zostali koronowani przez legata papieskiego ${ }^{19}$. Z kolei Tomasz Archidiakon napisał, że w tym samym czasie, gdy król węgierski Andrzej II wyruszył ze Splitu (do którego dotarł 23 VIII 1217 r.) na krucjatę do Ziemi Świętej, władca Serbii wysłał posłów do Rzymu, prosząc papieża o koronę królewską. W odpowiedzi papież wysłał swojego legata, który dokonał koronacji ${ }^{20}$. W historiografii powyższe dane źródłowe utarło się interpretować jako wskazujące na koronację w $1217 \mathrm{r}^{21}$, choć - o ile mi wiadomo - nikt nie przedstawił argumentów wykluczających datowanie tego wydarzenia na początek $1218 \mathrm{r}$. Dla niniejszych rozważań nie ma to jednak większego znaczenia.

16 И. Шпадијер, op.cit., s. 113-126 (povelja zależna od Żywota); B. Szefliński, Trzy oblicza, s. 81-82 (oba teksty zależne od wspólnego źródła).

${ }^{17} \mathrm{Z}$ poczynionych przez Solovjeva uwag można wywnioskować, że jego zdaniem przywilej został wystawiony w Chilandarze. А. Соловјев, ор.cit., s. 76, 78-79. Z kolei Slavica Vasiljević Ilić sądzi (błędnie), że Stefan nigdy nie opuścił Serbii, co oznaczałoby, że povelja musiała powstać w tym kraju. С. Васиљевић Илић, Српска средњовјековна књижевност, Бања Лука 2015, s. 72.

18 Стефан Првовенчани, s. 12-13.

${ }^{19}$ Andreae Danduli Venetorum Ducis Chronicon Venetum, a pontificatu S. Marci ad Annum usque MCCCXXXIX, w: Rerum Italicarum Scriptores, t. XII, ed. L. Muratori, Milan 1728, kol. 340-341.

${ }^{20}$ Thomae archidiaconi Spalatensis, Historia Salonitanorum pontificum atque Spalatensium, Latin text by O. Perić, ed., transl. and ann. by D. Karbić, M. Matijević-Sokol, J. Ross Sweeney, Budapest-New York 2006, s. 160-163 (tekst łaciński i angielski przekład).

${ }^{21}$ M.L. Burian, Die Krönung des Stephan Prvověnčani und die Beziehungen Serbiens zum römischen Stuhl, „Archiv für Kulturgeschichte”, 1932, t. 23, s. 146-148 (przegląd starszej historiografii); П. Јосиповић, Крунисање краља Стефана Првовенчаног у српској историографији, „Студије историје Иларион”, 2017, t. 1, s. 9-22 (zawierający drobne nieścisłości przegląd serbskiej historiografii). Ivana Komatina jeszcze bardziej zawęża datowanie - według niej koronacja miała miejsce najprawdopodobniej we wrześniu 1217 r. И. Коматина, Ана Дандоло - прва српска краљица?, „Зборник Матице српске за историју”, 2014, t. 89, s. 19. 
Znajdująca się w dokumencie tytulatura pozwala wyznaczyć terminus post quem non na 29 IX $1217 \mathrm{r}$.

2. Symeon jest nazywany w dokumencie, „świętym” (i to sześciokrotnie) ${ }^{22}$. Đorđe Bubalo całkiem słusznie zwrócił uwagę, że nie jest znany ani jeden przypadek, aby w serbskich dokumentach nazwano w ten sposób osobę, która nie została wcześniej za taką oficjalnie uznana ${ }^{23}$. Oznacza to, że przywilej powstał po jakimś wydarzeniu związanym z Symeonem, które współcześni uważali za warunek wystarczający do uznania jego świętości. Zdaniem Bubalo wydarzeniem takim było otworzenie grobu Symeona w Chilandarze (a następnie przeniesienie jego szczątków do Studenicy), podczas którego stwierdzono, że jego ciało (de facto kości $^{24}$ ) zachowało się w nienaruszonym stanie ${ }^{25}$. Trzeba jednak zauważyć, że w dwóch źródłach powstałych po tym wydarzeniu nie nazwano Symeona świętym ani razu, co oznacza, że dla współczesnych nie był to warunek wystarczający. Mowa tu o inskrypcji w tamburze kopuły katolikonu studenickiego informującej o wykonaniu fresków, a pochodzącej z 6717 roku ery konstantynopolitańskiej $(=1208 / 1209)^{26}$ oraz o, napisanym najprawdopodobniej po wspomnianej inskrypcji, Żywocie bt. Symeona wchodzącym w skład Typikonu studenickiego ${ }^{27}$. W pierwszym źródle Symeon jest nazwany „mnichem”28, a w drugim „po trzykroć błogosławionym” lub „błogosławionym”29. Powstanie w Studenicy, czyli w jednym z najważniejszych ośrodków związanych z osobą Symeona, dwóch źródeł niewspominających o świętości założyciela wyraźnie pokazuje, że warunkiem wystarczającym było inne, późniejsze wydarzenie. Musiała to być hierofania Symeona ${ }^{30}$, która miała miejsce najwcześniej 13 II $1210 \mathrm{r}^{31}$ Pozwala to wyznaczyć terminus ante quem non wystawienia povelji na 29 IX $1210 \mathrm{r}$.

${ }^{22}$ Стефан Првовенчани, s. 4-12.

23 Ђ. Бубало, ор.cit., s. 237.

24 Д. Поповић, Светитељско прослављање Симеона Немање: прилог проучавању култа моштмиу код Срба, ЗРВИ, 1998, t. 38, s. 47 і п. (=Д. Поповић, Светитељьско прослављање Симеона Немање: прилог проучавању култа мочтију код Срба, w: idem, Под окриљем светости: култ светих владара и реликвија у средњовековној Србији, Београд 2006, s. 27-40); idem, Мошти светог Симеона, w: Трећа казивања о Светој Гори, уред. Ч. Мирковић, М. Милосављевић, Београд 2000, s. $51-53$.

25 Ђ. Бубало, ор.cit., s. 237-238.

${ }^{26}$ Zob. wyżej przypis 12.

27 Свети Сава, Сабрана дела, прир. и прев. Т. Јовановић, Београд 1998 (dalej: Свети Сава), s. 146191 (tekst cerkiewnosłowiański i serbski przekład); B. Szefliński, Trzy oblicza, s. 80, 160, przyp. 32.

${ }^{28}$ Б. Миљковић, op.cit., s. 36-37.

${ }^{29}$ Свети Сава, s. 146-147, 152-153 i n.

${ }^{30}$ Zauważył to już Srđan Pirivatrić. С. Пириватрић, op.cit., s. 171, przyp. 26.

${ }^{31}$ Stanowisko przyjęte przeze mnie wcześniej (B. Szefliński, Trzy oblicza, s. 88-89) było nazbyt ostrożne. Nazwanie Symeona mnichem (a nie świętym) we wspomnianej inskrypcji z 1208/1209 r., na które położył ostatnio nacisk Miloš Živković (M. Živković, Studenica: The Funerary Church of the Dynastic Founder - the Corner Stone of Church and State Independence, w: Byzantine Heritage and Serbian Art, t. II: Sacral Art of the Serbian Lands in the Middle Ages, ed. D. Vojvodić, D. Popović, transl. T. Rodwell-Jovanović et al., Belgrade 2016, s. 202), pozwala jednoznacznie wykluczyć dzień komemoracji Symeona, który nastąpił w kilka dni po powrocie Sawy do Serbii. 
3. Stefan nadał Chilandarowi m.in. połowę Kamenicy, wsi leżącej w granicach Zety $^{32}$. Wskazuje to na posiadanie przez niego realnej kontroli nad tym terytorium. A zatem dokument nie mógł zostać wystawiony w czasie wojny domowej z Vukanem (starszym bratem Stefana i Sawy, który jeszcze za panowania ojca otrzymał Zetę jako dzielnicę) ani w okresie ją poprzedzającym, kiedy to narastało napięcie pomiędzy braćmi ${ }^{33}$. Najwcześniejszy możliwy moment to zakończenie wojny ${ }^{34}$, kiedy to zapewne Vukan uznał zwierzchnictwo Stefana, ale bardziej prawdopodobne jest, że do wspomnianego nadania mogło dojść dopiero po zakończeniu rządów Vukana w Zecie, co nastąpiło pomiędzy kwietniem $1207 \mathrm{r}$. a lipcem $1208 \mathrm{r}^{35}$

4. Stefan wspomina o swojej wizycie w Chilandarze, a konkretnie u grobu Symeona $^{36}$. Według Bubalo brak wzmianki o relikwiach Symeona spoczywających w grobie wskazuje, że Stefan był w Chilandarze, gdy kości jego ojca zostały już stamtąd przeniesione do Serbii ${ }^{37}$. Jest to oczywiście argument ex silentio, należy więc zachować ostrożność. Sądzę, że właściwsza jest koncentracja na tym, co jednoznacznie można wywnioskować $\mathrm{z}$ informacji zawartych $\mathrm{w}$ tekście, a nie $\mathrm{z}$ tych, których w nim nie ma. Wspomnianą w dokumencie podróż na górę Atos Stefan musiał odbyć w czasie, gdy po pierwsze Symeon został już pochowany, a po drugie Serbia utrzymywała dobre stosunki z państwem posiadającym zwierzchność nad Półwyspem Chalcydyckim, na którym góra Atos się znajduje. Na pewno było tak do momentu wypędzenia Eudoksji Angeliny, co nastąpiło w 1200 lub $1201 \mathrm{r}^{38}$ Drugi taki okres zapewne miał miejsce po uznaniu przez Serbów Henryka Flandryjskiego za legalnego

\footnotetext{
32 Стефан Првовенчани, s. 11-13; М. Благојевић, Хиландарски поседи на Косову и Метохији (XII-XVвек), X3, 2008, t. 12, s. 18-20.

33 J. Fine Jr, The Late Medieval Balkans: A Critical Survey from the Late Twelfth Century to the Ottoman Conquest, Ann Arbor 1994, s. 41-43, 47-49; М. Благојевић, Д. Медаковић, Историја српске државности, књ. 1: Од настанка првих држава до почетка српске националне револуције, Нови Сад 2000, s. 122-126.

34 Nie wiadomo, kiedy dokładnie wojna się zakończyła. Na pewno było to przed powrotem najmłodszego syna Nemanji do Serbii. B. Szefliński, Trzy oblicza, s. 68-69, przyp. 184, s. 76-77. Z moich ustaleń w kwestii sposobu rachuby lat przez Sawę wynika, że najprawdopodobniej wrócił on w 1207 lub 1208 r. B. Szefliński, Chronologia życia Stefana Nemanji: próba uporządkowania, „Roczniki Historyczne”, 2014, t. 80, s. 95-110. Warto w tym miejscu zwrócić uwagę, że rok 1206, również wskazywany przez niektórych badaczy (zob. Љ. Максимовић, О години преноса Немањиних моштију у Србију, ЗРВИ, 1986, t. 24-25, s. 437-438, przyp. 3), można raczej wykluczyć, ponieważ - czego nikt dotychczas nie dostrzegł - ze względu na rozpoczynający się 13 lutego Wielki Post komemoracja Symeona w tym roku musiała być przesunięta na wcześniejszy termin, prawdopodobnie 3 lutego, czyli byłaby przed przybyciem Sawy do Studenicy 9 lutego, a z hagiografii wynika, że była niedługo po nim. Na temat przesuwania komemoracji Symeona zob. Свети Сава, s. 144-145; М. Јанковић, Епископије и митрополије српске иркве y средњем веку, Београд 1985, s. 20-21; М. Марковић, Прво путовање светог Саве у Палестину и његов значај за српску средњовековну уметност, Београд 2009, s. 121, przyр. 52.

35 Ђ. Бубало, ор.cit., s. 239.

36 Стефан Првовенчани, s. 10-12.

37 Ђ. Бубало, ор.cit., s. 238.

38 М. Ласкарис, Византиске приниезе у средњевековној Србији, Београд 1926, s. 31.
} 
cesarza konstantynopolitańskiego ${ }^{39}$, czyli po najeździe Węgrów i Łacinników wiosną 1215 lub 1216 r. ${ }^{40}$ Jeśli chodzi o czas pomiędzy tymi okresami, to sprawa wygląda następująco. Po wygnaniu córki cesarskiej w poniżający sposób ${ }^{41}$ Stefan z pewnością nie miał wstępu na ziemie bizantyńskie co najmniej do detronizacji Aleksego III w lipcu 1203 r. W międzyczasie sam został pozbawiony tronu. Nie wiadomo, czy pozostał wówczas na terenie Serbii i cały czas prowadził walki z Vukanem, czy ratował się ucieczką z kraju. W tym drugim przypadku mógł się schronić albo w Bośni, albo w Bułgarii ${ }^{42}$, czyli u wrogów króla węgierskiego Emeryka, głównego sprzymierzeńca Vukana. Z Bośni nie miał możliwości udać się na Atos, a z Bułgarii raczej też tego nie zrobił. Sytuacja w Bizancjum nie była bowiem stabilna z powodu obecności wojsk IV krucjaty pod Konstantynopolem. Ostatecznie w 1204 r. cesarstwo bizantyńskie przestało istnieć, a na jego terenach stopniowo powstawały nowe państwa. Jednym z nich było Królestwo Tesaloniki utworzone latem-jesienią 1204 r. na ziemiach macedońskich, obejmujące również Półwysep Chalcydycki ${ }^{43}$. Nowym panem tych terenów był Bonifacy z Montferratu, który poślubił wdowę po cesarzu Izaaku II Angelosie, Małgorzatę, siostrę króla węgierskiego Emeryka. Tym samym Bonifacy stał się potencjalnym sojusznikiem Węgier ${ }^{44}$. Pielgrzymka na Atos byłaby więc wtedy ryzykowna. Co więcej wiosną 1205 r. rozpoczęła się wojna pomiędzy Bułgarią a Łacinnikami (w tym z Królestwa Tesaloniki), która trwała aż do śmierci cara bułgarskiego Kałojana jesienią 1207 r. ${ }^{45} \mathrm{~W}$ międzyczasie Stefan powrócił do Serbii (jeśli W ogóle ją opuścił). Wydaje się racjonalne przypuszczenie, że po powrocie na wielkożupański tron Stefan - aby nie ryzykować wznowienia wojny domowej - nie opuszczał kraju, dopóki Vukan pozostawał u władzy w Zecie. Od jesieni 1210 lub 1211 r. do 1214 r. podróż przez Macedonię znów nie była bezpieczna, bo władający częścią tego regionu wojowniczy Strez angażował się w liczne konflikty ${ }^{46}$. Z kolei od jesieni 1213 lub wiosny 1214 r. sam Stefan był zaabsorbowany odpieraniem ataków na

${ }^{39}$ F. van Tricht, The Latin „Renovatio” of Byzantium: The Empire of Constantinople (1204-1228), Leiden 2011, s. 402; С. Пириватрић, ор.cit., s. 172-173; S. Pirivatrić, The Serbs and the Overlapping Authorities of Rome and Constantinople ( $7^{\text {th }}$ to $16^{\text {th }}$ Century), w: Proceedings of the $23^{\text {rd }}$ International Congress of Byzantine Studies. Belgrade, 22-27 August, 2016, Plenary Papers, ed. S. Marjanović-Dušanić, Belgrade 2016, s. 232.

40 B. Szefliński, Trzy oblicza, s. 176, przyp. 7.

${ }^{41}$ Nicetae Choniatae historia, p. I: Praefationem et textum continens, rec. I.A. van Dieten, Berolini et Novi Eboraci 1975, s. 531; O City of Byzantium: Annals of Niketas Choniates, trans1. H. Magoulias, Detroit 1984, s. 291-292 (angielski przekład); Византијски извори за историју народа Југославије, t. IV, уред. Г. Острогорски, Ф. Баришић, Београд 1971, s. 164-165 (serbski przekład).

42 B. Szefliński, Trzy oblicza, s. 68-69, przyp. 184.

43 J. Fine Jr, op.cit., s. 60-75; Z. Pentek, Cesarstwo Łacińskie 1204-1261: kolonialne państwo krzyżowców czy Neobizancjum?, Poznań 2004, s. 69-94; F. van Tricht, op.cit., s. 41-53.

44 Z. Pentek, op.cit., s. 75; A. Madgearu, The Asanids. The Political and Military History of the Second Bulgarian Empire (1188-1280), Leiden-Boston 2017, s. 142.

45 Z. Pentek, op.cit., s. 95-119; A. Madgearu, op.cit., s. 146-171.

46 J. Wolski, ,Żywot św. Sawy” Teodozjusza Chilandarskiego jako źródło do dziejów Streza, władcy Proseku, „Balcanica Posnaniensia”, 2012, t. 19, s. 54-59. 
Serbię. Trwało to aż do wspomnianego wyżej najazdu Węgrów i Łacinników wiosną 1215 lub 1216 r. ${ }^{47}$ Dla okresu pomiędzy zakończeniem panowania Vukana w Zecie (po kwietniu 1207 r., ale przed lipcem 1208 r.) a rozpoczęciem wojen prowadzonych przez Streza (jesień 1210 lub 1211 r.) nie dysponujemy prawie żadnymi danymi istotnymi dla rozważanego tu zagadnienia. Jedynym wydarzeniem, które być może (ale niekoniecznie) miało miejsce we wskazanym przedziale czasowym, jest translacja kości Symeona z Chilandaru do Studenicy. Jeśli do niego doszło na początku 1208 r. $^{48}$, to nieco wcześniej, czyli w kilku ostatnich miesiącach roku poprzedniego, Stefan skierował do Sawy list z prośbą o przeniesienie szczątków ojca do Serbii ${ }^{49}$. Gdyby wielki żupan odwiedził Chilandar jesienią 1207 r., nie wysyłałby w tej sprawie listu, ale sam by sprowadził kości Symeona do ojczyzny. Summa summarum, z powyższych rozważań wyłaniają się trzy okresy, w których wizyta Stefana w Chilandarze była możliwa. Pierwszy obejmuje lata 1199 i 1200, a być może także 1201. Drugi - lata 1208 i 1209, a być może również 1207 i/lub 1210. Trzeci rozpoczął się w 1215 lub 1216 r.

5. Warto ponownie przyjrzeć się argumentowi Solovjeva, odrzuconemu przez Bubalo. O ile nazwanie Stefana zięciem cesarza Aleksego ${ }^{50}$ nie było tylko mechanicznym powtórzeniem tekstu przepisywanego z Pierwszej chilandarskiej povelji, to wskazuje na powstanie dokumentu w czasie, gdy Serbia uznawała Aleksego za legalnego władcę Konstantynopola. Było tak w czasie, gdy zasiadał on na tronie, ale również później - po powrocie Sawy do Serbii. Stan taki utrzymywał się najprawdopodobniej do zmiany polityki w tym zakresie wymuszonej przez konflikt z rzeczywistym władcą miasta nad Bosforem - cesarzem Henrykiem Flandryjskim ${ }^{51}$. Oznaczałoby to, że przywilej powstał przed wiosną 1215 lub $1216 \mathrm{r}$.

6. Znaczna część tekstu povelji wystawionych przez Stefana Nemanję i Stefana Nemanjicia jest zgodna ${ }^{52}$. Oznacza to, że autor tekstu ${ }^{53}$ późniejszego przywileju niewątpliwie miał przed sobą albo oryginał Pierwszej chilandarskiej povelji (jeśli pisał w Chilandarze), albo jej odpis (jeśli pisał w Serbii). Jeśli jednak odpis znajdował się w Serbii i był dostępny Stefanowi, to trudno wyjaśnić, dlaczego w ogóle z niego nie skorzystał, pisząc swój Żywot świętego Symeona. Jeżeli natomiast przywilej został wystawiony po powstaniu Żywota, to rodzi się pytanie: Dlaczego w treści dokumentu nie

${ }^{47}$ J. Wolski, op.cit., s. 58-59; И. Коматина, Историјска подлога чуда Св. Симеона у Житију Симеоновом од Стефана Првовенчаног, ЗРВИ, 2014, t. 51, s. 118-128.

48 Zob. wyżej przypis 34.

49 B. Szefliński, Trzy oblicza, s. 76-77.

${ }^{50}$ Стефан Првовенчани, s. 8-9.

51 С. Пириватрић, op.cit., s. 162-173.

52 Wygodne zestawienie porównawcze obydwu tekstów w: А. Соловјев, оp.cit., s. 82-89.

${ }^{53} \mathrm{~W}$ ostatnim czasie pojawiły się w opracowaniach wątpliwości, czy Stefan był rzeczywistym autorem tekstu dokumentu. M. Vukovojac, Stefan Nemanja: A Case of Sacral Kingship, London 2017, s. 1213 (rozprawa doktorska); М. Анђелковић, Савино Житије Светог Симеона и интертекстуалност, „Црквене студије”, 2019, t. 16/1, s. 338-339. Dopóki jednak nie zostanie udowodnione, że nim nie był, należy go za takiego uważać. Natomiast wskazywanie Sawy jako możliwego autora tekstu (ibidem, s. 338-339) jest najprawdopodobniej błędne. Kompozycja przywileju jest znacznie słabiej dopracowana niż ma to miejsce w dziełach najmłodszego syna Stefana Nemanji. 
ma żadnych odniesień do tekstu Żywota ani wydarzeń w nim opisanych, a w szczególności do cudownych interwencji Symeona pomagających Stefanowi pozostać na tronie? Pytanie to staje się szczególnie kłopotliwe, jeśli przywilej miałby powstać w Serbii. Powyższe trudności dotyczą również ewentualnego korzystania przez Stefana nie bezpośrednio z dokumentu wystawionego przez jego ojca, ale z tekstu zależnego od Pierwszej chilandarskiej povelji ${ }^{54}$. Trudności te natomiast nie pojawiają się, jeśli założyć, że przywilej Stefana Nemanjicia powstał w Chilandarze. A zatem zależności tekstologiczne (bądź ich brak) wskazują na wystawienie povelji właśnie w Chilandarze.

7. W dokumencie można znaleźć kilka zaimków wskazujących. Wydawałoby się, że mogą być one pomocne w ustaleniu miejsca powstania przywileju. Jednak już nawet pobieżna analiza porównawcza innych dokumentów wystawianych przez serbskich władców pozwala zauważyć, że w XIII w. zaimki te nie miały jeszcze na tyle sprecyzowanych znaczeń, żeby można było formułować na ich podstawie tego typu wnioski.

Podsumowując, problem czasu i miejsca powstania tak zwanej Drugiej chilandarskiej povelji wymyka się jednoznacznej interpretacji, ponieważ niektóre $\mathrm{z}$ argumentów obciążone są dodatkowymi warunkami, a tym samym ryzykiem błędu. Niemniej przedstawiona powyżej analiza wskazuje, że najbardziej prawdopodobne jest, że przywilej został wystawiony 29 IX 1210 r. w Chilandarze. Mniej prawdopodobne wydaje się powstanie dokumentu w tym samym miejscu 29 IX 1215 lub 1216, ewentualnie $1217 \mathrm{r}$.

\section{Źródla:}

\section{BIBLIOGRAFIA}

Actes de Chilandar, t. I, Des origines à 1319, éd. Mirjana Živojinović, Vassiliki Kravari, Christophe Giros, Paris 1998.

Andreae Danduli Venetorum Ducis Chronicon Venetum, a pontificatu S. Marci ad Annum usque MCCCXXXIX, w: Rerum Italicarum Scriptores, t. XII, ed. Ludovico Muratori, Milan 1728, kol. 9-524.

Barišić Franjo, Prevodi grčkih povelja o osnivanju srpskog Hilandara, „Književnost” 1986, t. 83/8-9, s. 1217-1228 [Баришић Фрањо, Преводи грчких повеља о оснивању српског Хиландара, „Књижевност" 1986].

Nicetae Choniatae historia, p. I: Praefationem et textum continens, rec. Ioannes Aloysius van Dieten, Berolini et Novi Eboraci 1975.

O City of Byzantium: Annals of Niketas Choniates, transl. Harry J. Magoulias, Detroit 1984.

Sveti Sava, Sabrana dela, oprac. i tłum. Tomislav Jovanović, Beograd 1998 [Свети Сава, Сабрана дела, прир. и прев. Томислав Јовановић, Београд 1998].

Stefan Prvovenčani, Sabrana dela, oprac. i tłum. Ljiljana Juhas-Georgievska, wyd. Tomislav Jovanović, Beograd 1999 [Стефан Првовенчани, Сабрана дела, прир., прев. и комент. Љиљана Јухас-Георгиевска, изд. Томислав Јовановић, Београд 1999].

${ }^{54} \mathrm{~W}$ tym niezachowanym do naszych czasów utworze musiałoby być zawarte to, co znajdujemy zarówno w Żywocie bt. Symeona, jak i w Drugiej chilandarskiej povelji, w tym alegoryczne porównanie góry Atos do raju. B. Szefliński, Trzy oblicza, s. 81-82. Mógł to być tekst stanowiący początkową fazę tworzenia przez Sawę żywota ojca. Istnienie takiego utworu wykorzystanego później przy pisaniu znanego nam Żywota postulowała Radmila Marinković. Р. Маринковић, Историја, s. 201-213. 
Thomae archidiaconi Spalatensis, Historia Salonitanorum pontificum atque Spalatensium, Latin text by Olga Perić, ed., transl. and ann. by Damir Karbić, Mirjana Matijević Sokol, James Ross Sweeney, Budapest-New York 2006.

Trifunović Đorđe, Bjelogrlić Vesna, Brajović Irena, Hilandarska osnivačka povelja svetoga Simeona i svetoga Save, w: Osam vekove Studenice: zbornik radova, Beograd 1986, s. 49-60 [Трифуновић Ђорђе, Бјелогрлић Весна, Брајовић Ирена, Хиландарска оснивачка повеља светога Симеона и светога Саве, у: Осам векова Студенице: зборник радова, Београд 1986].

Vizantijski izvori za istoriju naroda Jugoslavije, red. Georgije Ostrogorski, Franjo Barišić, Beograd 1971, t. 4 [Византијски извори за историју народа Југославије, уред. Георгије Острогорски, Фрањо Баришић, Београд 1971].

Zbornik srednjovekovnih čiriličkih povelja i pisama Srbije, Bosne i Dubrovnika, oprac. Vladimir Mošin, Sima M. Črković, Dušan Sindik, red. Dušan Sindik, Beograd 2011, t. 1 (1186-1321) [Зборник средњовековних ћириличких повеља и писама Србије, Босне и Дубровника, прир. Владимир Мошин, Сима М. Ћирковић, Душан Синдик, ред. Душан Синдик, Београд 2011].

\section{Literatura:}

Anđelković Maja M., Savino Žitije Svetog Simeona i intertekstualnost, „Crkvene studije” 2019, t. 16/1, s. 329-346 [Анђелковић Маја М., Савино Житије Светог Симеона и интертекстуалност, „Црквене студије” 2019].

Barišić Franjo, Hronološki problemi oko godine Nemanjine smrti, „Hilandarski zbornik” 1971, t. 2, s. 3158 [Баришић Фрањо, Хронолошки проблеми око године Немањине смрти, „Хиландарски зборник” 1971].

Blagojević Miloš, Hilandarski posedi na Kosovu i Metohiji (XII-XV vek), „Hilandarski zbornik” 2008, t. 12, s. 11-34 [Благојевић Милош, Хиландарски поседи на Косову и Метохији (XII-XV век), „Хиландарски зборник” 2008].

Blagojević Miloš, Medaković Dejan, Istorija srpske državnosti, Novi Sad 2000, t. 1 (Ot nastanka prvih država do početka srpske nacionalne revolucije [Благојевић Милош, Медаковић Дејан, Историја српске државности, књ. 1: Од настанка првих држава до почетка српске начионалне револуųuје, Нови Сад 2000].

Bogdanović Dimitrije, Istorija stare srpske književnosti, Beograd 1980 [Богдановић Димитрије, Историја старе српске књижевности, Београд 1980].

Bošković Đurđe, Nekoliko natpisa sa zidova srpskih srednjevekovnih crkava, „Spomenik Srpske kraljevske akademije” 1938, t. 87, s. 1-19 [Бошковић Ђурђе, Неколико натписа са зидова српских средюевековних иркава, „Споменик Српске краљевске академије” 1938].

Bubalo Đorđe, Kada je veliki župan Stefan Nemanjić izdao povelju manastiru Hilandaru, „Stari srpski arhiv" 2010, t. 9, s. 233-241 [Бубало Ђорђе, Када је велики жупан Стефан Немањић издао повељу манастиру Хиландару?, „Стари српски архив” 2010].

Burian Marie Luise, Die Krönung des Stephan Prvověnčani und die Beziehungen Serbiens zum römischen Stuhl, „Archiv für Kulturgeschichte”, 1932, t. 23, s. 141-151.

Đurić Vojislav J., Srpska dinastija i Vizantija na freskama u manastiru Mileševi, „Zograf” 1992, t. 22, s. 1327 [Ђурић Војислав Ј., Српска династија и Византија на фрескама у манастиру Милешеви, „Зограф” 1992].

Fine Jr John, The Late Medieval Balkans: A Critical Survey from the Late Twelfth Century to the Ottoman Conquest, Ann Arbor 1994.

Janković Marija, Episkopije i mitropolije srpske crkve u srednjem veku, Beograd 1985 [Јанковић Марија, Епископије и митрополије српске иркве у средњем веку, Београд 1985].

Jerković Vera, Jezik povelje velikog župana Stefana Nemanjića manastiru Hilandaru, „Zbornik Matice srpske za filologiju i lingvistiku” 1997, t. 40/2, s. 123-139 [Јерковић Вера, Језик повеље великог жупана Стефана Немањића манастиру Хиландару, „Зборник Матице српске за филологију и лингвистику" 1997].

Jerković Vera, Sintaksičke odlike hilandarske povelje Stefana Nemanjića, „Zbornik Matice srpske za filologiju i lingvistiku" 1998, t. 41/2, s. 19-33 [Јерковић Вера, Синтаксичке одлике хиландарске повеље Стефана Немањића, „Зборник Матице српске за филологију и лингвистику” 1998]. 
Josipović Petar, Krunisanje kralja Stefana Prvovenčanog u srpskoj istoriografiji, „Studije istorije Ilarion” 2017, t. 1, s. 9-22 [Јосиповић Петар, Крунисање краља Стефана Првовенчаног у српској историографији, „Студије историје Иларион” 2017].

Kašanin Milan, Srpska književnost u srednjem veku, Beograd 2002 [Кашанин Милан, Српска књижевност у средњем веку, Београд 2002].

Komatina Ivana, Ana Dandolo - prva srpska kraljica?, „Zbornik Matice srpske za istoriju” 2014, t. 89, s. 7-22 [Коматина Ивана, Ана Дандоло - прва српска краљииа?, „Зборник Матице српске за историју" 2014]

Komatina Ivana, Istorijska podloga čuda Sv. Simeona u Žitiju Simeonovom od Stefana Prvovenčanog, „Zbornik radova Vizantološkog instituta” 2014, t. 51, s. 111-134 [Коматина Ивана, Историјска подлога чуда Св. Симеона у Житију Симеоновом од Стефана Првовенчаног, „Зборник радова Византолошког института" 2014].

Laskaris Mihailo, Vizantiske princeze u srednjevekovnoj Srbiji, Beograd 1926 [Ласкарис Михаило, Византиске приниезе у средњевековној Србији, Београд 1926].

Madgearu Alexandru, The Asanids. The Political and Military History of the Second Bulgarian Empire (1188-1280), Leiden-Boston 2017.

Maksimović Ljubomir, O godini prenosa Nemanjinih moštiju u Srbiju, „Zbornik radova Vizantološkog instituta" 1986, t. 24-25, s. 437-444 [Максимовић Љубомир, О години преноса Немағиних моштмју у Србију, „Зборник радова Византолошког института” 1986 = Љубомир Максимовић, О години преноса Немањиних моттију у Србију, у: idem, Византијски свет и Срби, уред. Тибор Живковић, Београд 2008, с. 305-312].

Mandić Svetislav, Lađević Milan, Otkrivanje i konzerviranje fresaka u Studenici, „Saopštenja” 1956, t. 1, s. 38-41 [Мандић Светислав, Лађевић Милан, Откривање и конзервирање фресака у Студеници, „Саопштења” 1956].

Mandić Svetislav, Drevnik - zapisi konzervatora, Beograd 1975 [Мандић Светислав, Древник: записи конзерватора, Београд 1975].

Marinković Radmila, Istorija nastanka „Života gospodina Simeona” od svetoga Save, w: Sava Nemanjić - Sveti Sava. red. Vojislav Đurić, Beograd 1979, s. 201-213 [Маринковић Радмила, Историја настанка „Живота господина Симеона” од светога Саве, у: Сава Немањић-Свети Сава. Историја и предање, уред. Војислав Ђурић, Београд 1979 = Радмила Маринковић, Историја настанка „Живота господина Симеона” од светога Саве, у: idem, Светородна господа српска: истражсивања српске књижевности средњег века, Београд 2007, с. 99-114].

Marinković Radmila, Počeci formiranja srpske biografske književnosti: povelje o osnivanju manastira Hilandara, „Prilozi za književnost, jezik, istoriju i folklor” 1973, t. 39/1-2, s. 3-19 [Маринковић Радмила, Почеци формирања српске биографске књижевности: повеље о оснивању манастира Хиландара, „Прилози за књижевност, језик, историју и фолклор” 1973 = Радмила Маринковић, Српске повеље о оснивању манастира Хиландара, у: idem, Светородна господа српска: истраживања српске књижевности средњег века, Београд 2007, с. 39-56].

Marković Miodrag, Prvo putovanje svetog Save u Palestinu i njegov značaj za srpsku srednjovekovnu umetnost, Beograd 2009 [Марковић Миодраг, Прво путовање светог Саве у Палестину и његов значај за сриску средњовековну уметност, Београд 2009].

Miljković Bojan, Studenica, Bogorodičina crkva (1208/9), w: Gojko Subotić, Bojan Miljković, Irena Špadijer, Ida Tot, Natpisi istorijske sadržine u zidnom slikarstvu, red. Ljubomir Maksimović, Beograd 2015, s. 35-44, t. I (XII-XIII vek) [Миљковић Бојан, Студеница, Богородичина ирква (1208/9), у: Гојко Суботић, Бојан Миљковић, Ирена Шпадијер, Ида Тот, Натписи историјске садржине у зидном сликарству, уред. Љубомир Максимовић, Београд 2015].

Pentek Zdzisław, Cesarstwo Łacińskie 1204-1261: kolonialne państwo krzyżowców czy Neobizancjum?, Poznań 2004.

Pirivatrić Srđan, Grčki car Aleksije u prvim žitijima Svetog Simeona Nemanje, „Zbornik radova Vizantološkog instituta” 2016, t. 53, s. 161-178 [Пириватрић Срђан, Грчки цар Алексије у првим житијима Светог Симеона Немање, „Зборник радова Византолошког института” 2016]. 
Pirivatric Srđan, The Serbs and the Overlapping Authorities of Rome and Constantinople $\left(7^{\text {th }}\right.$ to $16^{\text {th }}$ Century), w: Proceedings of the $23^{\text {rd }}$ International Congress of Byzantine Studies. Belgrade, 22-27 August, 2016, Plenary Papers, ed. Smilja Marjanović-Dušanić, Belgrade 2016, s. 223-240.

Popović Danica, Mošti Svetog Simeona, w: Treća kazivanja o Svetoj Gori, red. Čedomir Mirković, Mirjana Milosavljević, Beograd 2000, s. 40-59 [Поповић Даница, Мошти светог Симеона, w: Трећа казивања о Светој Гори, уред. Чедомир Мирковић, Мирјана Милосављевић, Београд 2000].

Popović Danica, Svetiteljsko proslavljanje Simeona Nemanje: prilog proučavanju kulta moštiju kod Srba, „Zbornik radova Vizantološkog instituta” 1998, t. 38, s. 43-53 [Поповић Даница, Светитељько прослављање Симеона Немање: прилог проучавању култа моштију код Срба, „Зборник радова Византолошког института" 1998 = Даница Поповић, Светитељько прослављање Симеона Немање: прилог проучавању култа моштију код Срба, у: idem, Под окриљем светости: култ светих владара и реликвија у средњовековној Србији, Београд 2006, с. 27-40].

Radojčić Svetozar, Hilandarska povelja Stefana Prvovenčanog i motiv raja u srpskom minijaturnom slikarstvu, „Hilandarski zbornik” 1966, t. 1, s. 41-50 [Радојчић Светозар, Хиландарска повеља Стефана Првовенчаног и мотив раја у српском минијатурном сликарству, „Хиландарски зборник" 1966].

Solovjev Aleksandar V., Hilandarska povelja velikog župana Stefana (Prvovenčanog) iz godine 12001202., „Prilozi za književnost, jezik, istoriju i folklor” 1925, t. 5/1-2, s. 62-89 [Соловјев Александар В., Хиландарска повеља великог жупана Стефана (Првовенчаног) из године 1200-1202., „Прилози за књижевност, језик, историју и фолклор” 1925].

Stankova Radoslava, Sr'bskata knižnina prez XIII v. (kontekst i tekst), Sofija 2007 [Станкова Радослава, Сръбската книжнина през XIII в. (контекст и текст), София 2007].

Szefliński Błażej, Chronologia życia Stefana Nemanji: próba uporzadkowania, „Roczniki Historyczne”, 2014 , t. 80 , s. $95-110$.

Szefliński Błażej, Trzy oblicza Sawy Nemanjicia: postać historyczna - autokreacja - postać literacka, Łódź 2016.

Špadijer Irena, Alegorija raja kod Svetog Save i Stefana Prvovenčanog, w: PERIVOLOS: Zbornik u čast Mirjane Živojinović, red. Bojan Miljković, Dejan Dželebdžić, Beograd 2015, t. I, s. 113-126 [Шпадијер Ирена, Алегорија раја код Светог Саве и Стефана Првовенчаног, у: ПЕРІВОАОГ: Зборник у част Мирјане Живојиновић, уред. Бојан Миљковић, Дејан Џелебџић, Београд 2015].

Tricht van Filip, The Latin „Renovatio” of Byzantium: The Empire of Constantinople (1204-1228), Leiden 2011.

Trifunović Đorđe, Natpisi uz portrete Nemanjića u manastiru Mileševi, „Književnost i jezik” 1992, t. 39/2-4, s. 91-100 [Трифуновић Ђорђе, Натписи уз портрете Немањића у манастиру Милешеви, „Књижевност и језик” 1992].

Vasiljević Ilić Slavica, Srpska srednjovjekovna književnost, Banja Luka 2015 [Васиљевић Илић Славица, Српска средњовјековна књижевност, Бања Лука 2015].

Vukovojac Marija, Stefan Nemanja: A Case of Sacral Kingship, London 2017.

Wolski Jan M., ,¿̇ywot św. Sawy” Teodozjusza Chilandarskiego jako źródto do dziejów Streza, władcy Proseku, „Balcanica Posnaniensia”, 2012, t. 19, s. 51-69.

Živković Miloš, Studenica: The Funerary Church of the Dynastic Founder - the Corner Stone of Church and State Independence, w: Byzantine Heritage and Serbian Art, t. II: Sacral Art of the Serbian Lands in the Middle Ages, ed. Dragan Vojvodić, Danica Popović, transl. Tamara Rodwell-Jovanović et al., Belgrade 2016, s. 193-209.

Živojinović Mirjana, Istorija Hilandara I: Od osnivanja manastira 1198. do 1335. godine, Beograd 1998 [Живојиновић Мирјана, Историја Хиландара I: Од оснивања манастира 1198. до 1335. године, Београд 1998]. 